[Scott, A. (1993). Teacher Training in 1992: A Review and Discussion. New Zealand Annual Review of Education, 2, 107-118]

\section{Teacher Training in 1992: A Review and Discussion}

\section{ALAN SCOTT}

$\mathrm{F}$ or people who worked in colleges of education, in particular for academic staff, 1992 was the year of living nervously. Like Dad's Army peering across the English Channel in 1939, lecturers cast their eyes towards Wellington to glean the first signs of the anticipated attack on teacher training. The signs were ominous and the threats very real. There was the Minister of Education's supposed sympathy for an apprenticeship model of training, the State Services Commission's well known position on award negotiations, backed by the power of the Employment Contracts Act, and as if that was not enough, capitalism's Avenging Angels at the Business Roundtable had commissioned a report into teacher training. On top of all this the spirit of Thatcher's enterprise culture had permeated the walls of The Colleges of Education so that there was talk everywhere of the need for entrepreneurial activities, activities which threatened to turn teacher trainers into pedlars of merchandise.

As it turned out, the attack was a fizzer. In Gramsci's terminology, albeit in reverse form, 1992 saw the war of manoeuvre over teacher training rather than the war of position. The full frontal attack, this time from the state against one of its own relatively autonomous institutions, never actually materialised. Civil society, in the form of the basic liberal discourse about the training of teachers, still breathes relatively easily, though, it must be said, with increasing difficulty. Award negotiations, while entering their final phase, had not by the end of the year reached anywhere near a conclusion. The Roundtable report has not been published, and is still a few months away, though no one knows why, or is not telling. Entrepreneurial activities have come, some have gone, but none has, as yet, swamped the basic purpose and meaning of teachers' colleges.
For college of education students, or trainees as they are often known, in particular for those graduating in December, 1992 was the year of living anxiously. On recalling the period of the French Revolution Wordsworth had said:

Bliss was it in that dawn to be alive

And to be young was very heaven.

In the midst of the monetarist counter revolution with its attendant rhetoric of cuts in state spending teacher trainees live in limbo, and one could glean, even through their carousings at Happy Hour, the sense of insecurity and uncertainty the shrinking job market has brought. Colleges exist only for their students, and the students are there only for one purpose. While universities concentrate on research as well as teaching, colleges have traditionally directed all their energies towards professional training. Similarly, while a degree may open many doors a college of education diploma provides only one avenue of employment. When this avenue turns into a bottle-neck, as it did in 1991, with instances of a hundred or more students applying for a single job, then anxiety fills the space as the raison d'être shrinks.

The problem of a diminishing employment market is particularly acute in Colleges of Education, and 1992 saw the early development of what might prove to be a profound institutional schizophrenia. College lecturers, as a group, have vigorously resisted the dogma and tenets of methodological individualism. Imbued with the liberal educational vision that grew out of the Long Boom of capitalist post-war expansion they have clung doggedly to the cornerstone of equality of opportunity, and have embraced the concept of individuals as self actualising human beings whose worth is as much to the wider social cooperative as to themselves. It is no accident that college staff have taken to heart cooperative learning theory and strategies à la Johnson and Johnson, for cooperative learning theory focuses on the two pivots of social democracy: individual achievement through and within a framework of social welfare and practices.

This social sense of individuals as self actualisers contrasts markedly with neo-classical economic theory's perception of individuals as rational utility maximisers, and herein lies the contradiction between the world of belief the trainees inhabit at college and the world of reality they face at graduation. They are taught cooperatively to teach cooperatively. They are forced by the market to seek employment 
competitively. This is no droll or cynical observation, for a sharp and dangerous tension exists here. For the first time in many years we saw in 1992 students asking for a "proper" assessment of courses, and for the end of the pass/fail grading in favour of $A, B, C$ ranking, that they might better be able to distinguish their $\mathrm{CVs}$ from the profiles of their peers.

\section{Models of Training}

If all this is by way of a long introduction to the question of what happened to teacher training in 1992, it is because what happened is to be found in the nervous systems of the students and teachers of the colleges of education and not in any action or reaction over policy. Certainly, as we shall see, there was a stand-offover award negotiations, and little love was lost between both sides, but in terms of the daily business of training students to be teachers the colleges ploughed on much the same as usual. 1992 was a year of consolidation for management, staff and students who had finally adjusted to the effects of the Education Act 1989 and the Education Amendment Act 1990 which devolved management autonomy to tertiary education institutions and allowed them to manage their own resources, subject to a public accounting for their performance. The Audit Office's report Allocation of Funding for Teacher Education (1992, p. 13) emphasises the level of change the two acts brought about:

For colleges of education, this represented a considerable change from the previous regime where the former Department of Education closely regulated their staffing levels, salaries, courses, student intake levels, and student recruitment. Colleges had limited discretionary spending or decision-making power.

Early in the third term the rumour circulated that school based training would be introduced in 1993 for intending secondary school teachers. In the event, the rumour proved unfounded. The exact source of the rumour is irrelevant, but its generalised sources in terms of ideas and actions that underpin the apprenticeship model are worth recording.

1. The Government's proposal for some university graduates to train under the direction of approved head teachers, as promised in the election manifesto.
2. Voluntary registration of teachers which suggests a lack of commitment to college based training.

3. The expectation that New Zealand would follow the British model which heavily increased the time spent in schools during training.

4. Theimpending publication of the Business Roundtable's report which was expected to mirror the Lawlor report in Britain.

5. The tenet of New Public Management theory which deals with the self-interest of state servants, in this case college lecturers.

6. The sounding out by some secondary schools of the possibility or feasibility of running training schemes.

7. The nuts and bolts, new reality approach of neo-liberalism.

8. The never mentioned in public, but whispered in private threat by Bill Birch to cut teacher training if lecturers did not toe the line on site agreements. Or so the rumour goes.

Rumour or not, the threat to transform training from a college based model to a school based model was, and is, very real. The reason for this is that the debate is an on-going debate which exists outside any particular New Right formulation of it. It is worth re-emphasising here what we already know: namely that right wing policies which are successful hook into pre-existent ideas and practices and transform liberal debates, rather than simply demolish them. The reason the changes to the British system of teacher training were accomplished so easily was that teachers in the United Kingdom did not oppose them in any vigorous manner. Indeed many supported them because the teacher training policy of the Tory party confirmed what many teachers felt they already knew: that teacher training was too theoretical, and lacked a sufficiently practical component.

The teachers knew this because they subscribed to the reflection in action model of training, the view of the teacher or trainee as a reflective practitioner, though, of course, most of them could not articulate it in this way, and would not necessarily know that the model had a name and a literature to support it. College lecturers, on the other hand, opposed the changes not out of self interest, at least not mere selfinterest, nor because they were political zealots from the left, as the New Right argued, but because they supported an opposite and well articulated model. This model, the liberal rationalistic view of teacher 
training, far from being a model of the left, gained much of its support from the London Institute of Education in the days when middle-of-theroaders like Peters and Hirst reigned supreme. The liberal rationalistic view of teacher training seeks to give trainees a thorough background in educational theory which is distinct in time and place from their own practice. One can argue, as the right wing drum beaters do, that the theoretical component has too much sociology, or too much philosophy, or concentrates on anti-racism, or whatever, but the argument is as much a quibble over content, as over the model of training itself.

In a similar vein, it is argued that the reflection in action model often comprises in practice, if not in intent, too much action at the expense of reflection. This legitimates poor teaching, as bad practice is allowed to continue unmediated by reference to research and sound theory. Again, it is not the model itself, but the particular formulation of it which is the issue.

There is not space in this review to do justice to the debate over teacher training. As Barrie points out, the dichotomising of teacher training schemes into two different and opposing models is simplistic in the extreme. What is clear is that New Zealand teachers, while happy, like practitioners in any field, to have a joke at the expense of those at the talk face, do not in any meaningful sense oppose the college based model. There is certainly no ground swell within the teaching profession which would allow any government to easily introduce an apprenticeship scheme. Part of the reason for this is that teacher training is going from strength to strength in terms of effectiveness. Students are trained better now than they have ever been, and teachers know it. Unfortunately, it goes without saying that colleges of education, at any rate New Zealand colleges of education, have no objective evidence, in the academic research based sense, for this; only feelings, hearsay and letters of commendation. However, 1992 has seen a general commitment from management and academic staff to the idea of colleges as research institutions. It is obvious where some of that research must be directed.

While there is no space here to discuss the issue, it is worth pointing out that colleges of education are keen to begin the process of engaging in serious research, possibly even incorporating research roles into the job descriptions of lecturing staff, as a precursor to their issuing degrees under their own steam. It is almost certain that those colleges which will remain as stand-alone institutions will begin degree programmes within the next two or three years. In his Wellington College of Education address Lockwood Smith clarified the Government's position on relationships with universities. Affiliation or amalgamation is looked upon favourably, but will not be enforced. Given the volatility of what has essentially become the EFTS market in tertiary education, standalone institutions may well need to offer degrees in order to compete. Over and above these vagaries of education's very own Futures Market, colleges of education, as specialist institutions, are very capable of offering specialist degrees. There has been a noticeable trend, not just in 1992, but for the last few years, for lecturers to upgrade their qualifications. Excellent teaching experience alone is no longer enough to gain a well respected practitioner a position at a college of education.

Precisely why the report commissioned by the Roundtable has been delayed or withheld is not known. Communication with the Roundtable elicits the response that the report is being completed as commissioned and will be out within some months. Scuttlebutt tells another tale, which is that the author did not find what the Education Forum expected him to find: an outmoded, ethereal model of training tinged red and purple by lefties, lesbian feminists and the New Zealand chapter of the ANC. Indeed, it is rumoured that he actually found most of the content of the course to be relevant.

Whatever the case, the debate for 1992 was brought to an abrupt end by the Minister of Education in a speech at Wellington College of Education on October 6, in which he discussed the apprenticeship model. Lockwood Smith said:

It appears that at present too much of the debate is focused on whether or not teacher education should follow the apprenticeship model or be seen as an academic discipline. Personally I find such debate unnecessary. If one were to ignore the political angle of his work, Professor [lvan] Snook quite successfully ended the debate, in my opinion, in a speech in Auckland when he pointed out the great importance of both the theoretical and the practical. To quote him: "The continuing controversies about theory and practice are among the most obdurate and the most absurd. Teachers have a complex task to perform and their preparation needs to be correspondingly complex; their work requires depth of understanding and their educa tion must be correspondingly abstract. But this does not mean, and indeed cannot mean, a reliance on theory or abstractions alone." 
While it is clear that the matter ends there in terms of the wholesale adoption of a school based scheme, at least within the foreseeable future, it is also clear that the Minister of Education is determined to have a bob each way, and leave his options open. Later on in the same address to the Wellington College of Education forum on teacher education he has this to say about the graduate Teacher Trainee Scheme which was promised in the election manifesto:

That proposal would allow university graduates, without teaching qualifications, but with strong backgrounds in, say, maths and science, to train under the direction of head teachers in schools. They would beenrolled in Colleges of Education to ensure they developed the theoretical knowledge and understandings they need to be effective teachers. However they would spend the majority of their time in schools.

The key words here are "enrolled in Colleges of Education to ensure they developed the theoretical knowledge and understandings they need to be effective teachers." If this is taken to mean that colleges will have control of both the content and process of the training course, then we have a proposition that is worth debating. As was suggested above, polarising the argument in terms of school based or college based options is too simplistic. There are thoroughly bad examples of both models.

If, however, these words are taken to mean that schools will largely control the training, that trainees will be nominally enrolled at colleges, but will spend time there like apprentice butchers on their half day at Poly., then Lockwood Smith has a fight on his hands. This would be too close to the new British system, which would be favoured neither by college lecturers nor school teachers.

Again, it is necessary to reiterate that, from the point of view of college staff, it is not a question of mere self-interest. Whatever the devotees of Adam Smith may think, all of us in education know that there are some things inside ourselves that do not begin with dollar signs, and that there is one thing outside of ourselves, namely the notion of community, that is worth preserving. It is not simply a question of support for college based training because it pays the mortgages. Christchurch College of Education, for example, is trialling a school based model in the Secondary Division with one group in 1993, which will be compared with its current model. The real point to be made is that teacher training in New Zealand, while still college based, has changed dramatically in the last few years. So much so, that teachers trained as little as ten years ago hardly recognise their places of training. The incorporation of Professional Studies, and the move to competency based training, along with the increased emphasis on education studies, has removed the worst excesses of the liberal rationalist model of teacher education as an academic discipline. It has given training a focus which is both practical and educationally coherent. At the same time it has avoided the pitfalls of the school based, mentor system, the do as I do, action-without-reason model

We should note, also, that the competency based models currently used or being formulated in the colleges of education have not simply been generated as a response to the demands of the New Zealand Qualifications Authority's "learning outcomes" model of course writing. Christchurch College of Education began its own research into competency based training as early as 1987. Its aim was to produce a liberal model which also made teacher training accountable from the point of view of staff to students, college to the state and state to parents.

Opening the competency debate over teacher training at this point, as at any point, would be like opening the proverbial can of worms. The debate is long standing and essentially boils down to a view of competencies as discrete skills which can be measured as behaviours or performances, or a view of competencies as "desirable attributes in the process of developing rather than as end states." (Davis and Zaret, 1984) The first view, originally derived from behavioural theory, allows training schemes to have a "gate-keeping" function: students pass over the threshold when all their boxes have been ticked. The second view adopts an holistic, global account, insisting on a developmental approach which sees training taking place before, during and after college.

The point to make here is that colleges of education are very well aware of this debate, sometimes only implicitly, it is true, but increasingly in an explicit fashion. They are devising schemes which rationalise both positions, and create programmes which are developmental and, at the same time, accountable both to the customers and to the country. NZQA's "learning outcomes" formulations seem blind to this debate. Whatever the heuristic potential of NZQA's adoption of Total Quality Management, and there are immense benefits 
in it for education, let us be clear that, like the Nissan way's democratic potential, its radical potential is borne out of the conservative urge that a capitalism in recession produces, to be competitive, efficient and lean. Competency based training can be a mechanism for de-skilling, controlling, robotising and essentially underpaying and exploiting a workforce. Competency based teacher training, therefore, can be the first step in the proletarianisation of the teaching profession, or it can be the beginning of the process to rationalise the debate over which model of training to use, and what kind of teacher to produce. Colleges of education in 1992 are stronger than ever in their view of what makes a good teacher and in their capability to turn the vision into reality. It remains to be seen whether New Right ideology paints them into a corner.

\section{Award Negotiations}

By the end of 1992, no industrial settlement had been reached in any college between employers and academic staff, though local site agreements had been concluded with general, clerical, maintenance and grounds staff. There is not the space in this review to traverse every track of the hazardous route taken by the negotiators from both sides. The union to which college of education lecturers belong, the Association of Staff in Tertiary Education, sought the continuance of a national award. The employers, the principals of the colleges, now called Chief Executive Officers, wanted some form of site based collective. The year ended with ASTE acceding to the idea of local, college based negotiations and agreements, but not on the terms and conditions wanted by the CEOs, and with negotiations conducted at each site by the national team from Head Office, not by the local team desired by the employers. There is a very real stand-off, and emotions and feelings have run very high on both sides.

Rather than describe the intricacies of the negotiations, it is only necessary here to make a fundamental observation. The dispute is as much about ideas as about real conditions and events. The lecturers want the dispute sorted out in the traditional manner. They subscribe essentially to the Keynesian settlement, that concept of a negotiated social accord which grew out of the Long Boom of capitalist expansionism which followed the Second World War. The employers as a group, whether individually committed or not, meet them with the language and concepts of neo-classical economic theory.
That the dispute is more about ideology than the specifics of training teachers is not difficult to show. In the first place, individual CEOs, when pressed, will confirm that there is nothing that they could do under a new settlement, that they cannot do, at present, under the national system of agreement. This obviously prompts the question: why struggle so arduously then for a new type of accord? Secondly, contrary to the intent and supportive propaganda of the Employment Contracts Act, which asserts the centrality of "free" contractual bargaining between two parties, there is clearly a second tier of bargaining going on between the employers and advisers from the State Services Commission. The employers take proposals from ASTE to the State Services Commission and argue with them over their acceptability. This process is no secret, and to be fair to the principals they are clearly caught in a cleft stick.

Thirdly, the New Right, in the form of the Minister, the State Services Commission, the Audit Office and the Roundtable has been unable to produce any shred of evidence at all that colleges of education are inefficient, wasteful, or inadequate in their ability to produce quality teachers. Indeed, as we all know, from newspaper reports and other sources, New Zealand teacher training is held in the highest regard internationally. The inescapable conclusion from this is that change, in this instance, is being pursued for change's sake. It is being pursued to bring another sector of the state into line with the industrial and commercial sector. In other words, the movement against the national award is driven by ideology and not by necessity. In terms of the contested terrain thesis of the neutral state, the industrial dispute at colleges of education represents the further encroachment of commerce into previously alien territory. Under Bowles and Gintis's thesis of the social accord it indicates the hegemony of property rights over personal rights. To a Marxist, the analysis is basically straightforward. What we have is the class struggle being taken by the bosses to the workers.

To college of education staff, who generally do not think in these global theoretic terms, the dispute is a stressful and pointless exercise which gets in the way of their personal and communal mission to produce high quality teachers. There is no doubt that in 1992, looking towards the future, lecturers know better than at any time in the past how to accomplish this. It remains to be seen whether Government and their friends in the ideological think tanks will allow them to do so. 


\section{Postscnpt}

Since this article was written the Education Forum has released in draft form the report into teacher training referred to in the paper as the Roundtable Report. This draft was "leaked" and is now readily available. The editor of the Annual Review has asked me to pen a few, brief comments.

In general terms the report is fairly positive. It has little of the swaggering, bombastic criticism that has characterised previous Forum reports and comments, and the utterances of the Right's other propaganda factories. It says what many of us expected it to say, but without the vehemence and intensity we have known in the past. Clearly the authors found much of value in current training practices. As the report puts it:

The overall message is a positive one ... Colleges of education are generally responding well to the new policy environment. There is clear evidence that the earlier criticisms are being addressed and, in many cases, overcome. A new enthusiasm is evident.

Many of the issues tackled in the report such as selection procedures, evaluation of student performance, content of courses and programmes, and college-based versus on-the-job-training are vital issues which are already being addressed by colleges (if somewhat belatedly in some cases), and need to be further addressed. The Education Forum's contribution in these areas is most welcome. At the same time, by the end of the report, one cannot help but feel that here was an idea, a belief, a prescription in search of some evidence, rather than that some data about teacher training was requiring an explanation. In other words, if you wish to set to rights teacher training you are first required to show where it went wrong. This is what the Report fails to do.

For this reason the whole comparative chapter of the report on "An international perspective of teacher education" is virtually worthless. To be sure, training in the UK, Australia and the USA is problematic, possibly even for the reasons outlined, but New Zealand's system of training resembles these other systems hardly at all. Haberman's well known and trenchant criticisms of America's university-based teacher education system cannot be made to fit our own college-based system which is trying to resolve the thorny theory/practice polarisation through a competency-based approach. To echo what has already been said in this article, the Education Forum's report does not offer any substantive evidence that colleges of education in New Zealand have failed their students, their schools or their country. It has not shown, and indeed cannot show, that college graduates are ineffective teachers who are letting down their charges. We all know, of course, what has really failed our children: the principles, practices and policies of monetarism which have created worlds without work and childhoods without hope. The report makes a lot of noise. It claims to beat its drums in the cause of better teaching. One suspects its real purpose is a diversion to drown the cries of the innocent.

\section{References}

Audit Office "Allocation of Funding for Teacher Education" November 1992.

Bowles, S. and Gintis H. Democracy and Capitalism: Property, Community and the Contradictions of Modern Social Thought. New York: Basic Books, 1986.

Barrie, J.“Oxford and Cambridge theorising: some thoughts on initial teacher education" in Educational Philosophy and Theory 24, 1, 1992.

Davis, M. and Zaret, E. "Needed in teacher education: a developmental model for evaluation of teachers" in Journal of Teacher Education, 35, 5, 1984.

Monoghan J. and Lunt, N. "Mentoring: person, process, practice and problem" in British Journal of Education Studies, 40, 3, 1992.

Schon, D. The Reflective Practitioner. London: Temple Smith and New York: Basic Books, 1983.

Whitty, G. "Quality control in teacher education" in British Journal of Education Studies, 40, 1, 1992.

\section{The author}

Alan Scott is a Principal Lecturer, Coordinator of Professional Studies, at the Christchurch College of Education. His interests are in the politics and sociology of education. 